\title{
Exploration on the Training Mode of Management Masters Based on Innovation Ability
}

\author{
Liping Lin \\ School of Economics and Management \\ Guangxi University of Science and Technology \\ Liuzhou, China
}

\author{
Juan Wang* \\ School of Economics and Management \\ Guangxi University of Science and Technology \\ Liuzhou, China
}

\begin{abstract}
Postgraduate education is the main way to cultivate high-level talents needed by the country and the cornerstone of national development and social progress. This paper takes the innovation ability as the orientation, faces the local university graduate student teaching reform, carries on the thorough exploration to the management specialized graduate student training mode, proposed to construct the management graduate student innovation ability training mode which takes "the goal orientation" and "the talented person training entire process quality control" as the core. This paper expounds the train of thought and suggestions for training and improving the innovative ability of management postgraduates, hoping that these ideas and suggestions can provide some reference and help for the training work of management postgraduates.
\end{abstract}

Keywords - postgraduate education; innovation ability; training mode; master of management

\section{INTRODUCTION}

Innovation is the primary driving force for development and the strategic support for building a modernized economic system[1]. To speed up the construction of an innovationoriented country, it is crucial to cultivate a large number of high-level talents with innovative ability. The innovative spirit and ability of a country enable it to seek a dominant position in the fierce international competition and create important preconditions for the development of national economy and the consolidation of world status. Therefore, in order to adapt to the world economic development and the accelerating process of China's social transformation, the country has a more urgent need for all kinds of innovative talents, especially for high-level management talents.

Graduate education is an important way to cultivate highlevel innovative talents in China and an important export channel. The cultivation of postgraduates plays an important role in graduate education. Graduate education, as a key part of higher education, provides a steady stream of talents for a country's economic and social development. Management majors have been attached great importance to in the economic and social development, and have cultivated a large number of management professionals for the development of the country and the transformation of enterprises. In their opinions on deepening the reform of graduate education, the ministry of education and the ministry of finance pointed out that since the reform and opening up, China's graduate education has made great achievements and basically achieved the strategic goal of cultivating high-level talents based on the domestic market. In general, China's postgraduate education has developed rapidly in quantity and scale. However, the cultivation of students' innovative ability in postgraduate education still cannot meet the needs of the social development, nor can it fully adapt to the diversification of economic and social development needs. The quality of innovation ability training also has a certain gap with the international advanced education level. Therefore, the cultivation of high-level talents with innovative spirit and ability has become an important direction of the future graduate training model.

At present, China is in a new era of socialism with Chinese characteristics. The national economic development and social transformation have more urgent needs for innovative talents, and higher requirements have been put forward for the cultivation of innovative ability of postgraduates. In order to meet the needs of economic and social development, the department should cultivate more high-level innovative management talents. Therefore, this thesis conducts in-depth exploration and research on the postgraduate training mode, in order to improve the students' innovative ability as the teaching focus, and puts forward the "target orientation" and "the whole process of talent cultivation". As the core of the postgraduate training model management innovation ability, quality control cultivates graduate research ability, innovation ability, practical ability and teamwork ability.

\section{ThE CONNOTATION OF POSTGRADUATE TRAINING MODE}

The quality of postgraduate education is an important factor affecting a country's core competitiveness. Different scholars have put forward their own opinions on the understanding of the specific meaning of "postgraduate training mode". This paper makes the following elaboration on the viewpoints of the main scholars.

Professor Yuanqing Zhou in 1998, the ministry of education "for the first time the national ordinary university teaching work conference", first expounds the reasons are as follows: "training mode, is actually the talents training target, training specifications and the way of basic training, it clearly reflected the education ideas of higher education and the education idea, defined the basic characteristics of training talents[2]." Professor Zefang Dong (2009) to understand the concept of the postgraduate training mode to, in the traditional thoughts and concepts of graduate student training support,

Innovation Project of Guangxi Graduate Education (No.JGY2018108). 
according to the rule of graduate education and social needs, by training subject, training objects, training concept, training standards, training methods, training appraisal system and so on elements, has the characteristics of some typical and relatively stable theory model and operating pattern[3]. Professor Sihui Cheng (2010) argues that the graduate cultivation model is according to the demand of talents growth law and society in a certain education idea, education under the guidance of the theory and specific requirements, to achieve a certain goal of graduate education, makes the graduate cultivation between subject and object of graduate student training is the basic link of the training mode of the deal[4]. Postgraduate training pattern is actually a concise summary of characteristics of graduate education, it is to express in the body of the elements of graduate student training "cultivating what kind of graduate student" and "how to train graduate students" are two basic problems in the process of postgraduate education concrete solving measures and solutions, and centered on the postgraduate training point of view, the graduate student training mode can be divided into the government's leading mode, such as leading mode, the unit of disciplines leading pattern in colleges and universities. Some scholars believe that the postgraduate training mode refers to the knowledge, ability, quality structure and the overall operation mode of realizing this structure under the premise of following the law of talent growth and social needs.

By sorting out the views of the above scholars, it can reflect the postgraduate training mode in the new era. On the basis of following the law of talent growth, it is necessary to meet the needs of the society and cultivate high-level talents in line with social development and the trend of The Times. This not only reflects the characteristics of The Times, but also reflects the educational thoughts and ideas in the new era.

\section{EXPLORATION ON THE TRAINING MODE OF MANAGEMENT MASTERS BASED ON INNOVATION ABILITY}

In order to achieve the rapid development of the quality of postgraduate education, meet the urgent needs of innovative talents in the development of the new era and social transformation, cultivate high-level management innovation talents, further promote the innovative reform of the postgraduate training model, build a "target-oriented" and "quality control of the whole Process of talent cultivation" as the core of management innovation ability of postgraduate training mode, we urgently need to explore new ideas and countermeasures in the postgraduate training mode.

\section{A. Cultivating the Innovation Ability of Management Masters with the Core of "target-oriented"}

The training mode of innovative ability for management postgraduates with "target-oriented" as the core solves the problem of "what kind of postgraduates should be cultivated", that is, in the process of talent training for postgraduates, we pay most attention to the cultivation and improvement of the abilities and qualities of postgraduates. In the new era of socialism, to achieve a qualitative leap in the quality of graduate education in China, we must pay attention to the cultivation of innovative thinking and innovative ability of graduate students, and cultivate high-end talents with innovative ability to lead the development of all walks of life. With the gradual formation of a new world pattern, whether a country has the spirit of innovation will become an important condition for national development and national status consolidation. Cultivating the spirit of innovation and innovation is a necessary condition to meet the diversified needs of China's economic and social development. Therefore, as the main way to cultivate high-level talents, postgraduate education should be oriented by the goal of innovation ability and spirit, adapt to the national development and social needs, and develop the potential of positive creation of postgraduates to the greatest extent.

\section{B. Cultivating the Innovation Ability of Management Masters with the Core of "Quality Control in the Whole Process of Talent Cultivation"}

With the core of "quality control in the whole process of talent training", the innovative ability training mode for management postgraduates solves the problem of "how to train postgraduates" and improves the innovative willingness and potential of postgraduates through the innovative talent training mode. The quality of talent training is a process of gradual formation. The key to ensuring the quality of talent training is to pay attention to the quality control of the whole process of talent training. Therefore, quality control should be carried out in the whole process of talent cultivation, including the concept, goal, mechanism, recruitment system and curriculum system construction.

\section{1) Changing the concept of postgraduate training}

The Ministry of Education's development goals for China's higher education are as follows: talent supply and innovation capabilities have been significantly improved, innovation, interdisciplinary, application and technical personnel training ratio has been significantly improved, more innovative talent training structure is rationalized, and higher education innovation level is developed. And some university's abilities and some disciplines have become world-level. Under the leadership of world-level disciplines, some new ideas for strategic innovation bases serving the country have been established in colleges and universities, and innovative service capabilities have improved. A number of major innovations have emerged. The competitiveness of national innovation. This development goal of higher education requires graduate education to change its concept, focus on the international market, and highlight the core of innovation ability training. The concept, model, curriculum and content of graduate education should be modern and innovative. Colleges and universities should promote the integration of postgraduate education and world education with a broad vision and ideas, and with China's economic and social development stage, scientific research and practical application, thus becoming a training base for higher education.

\section{2) Focusing on graduate training objectives}

In terms of postgraduate training objectives, we should deepen the cooperation between universities and innovative enterprises, social enterprises and foreign scientific research institutions around the national strategic goals, so that all innovative resources and elements will be gathered in universities to jointly build a cooperative mode of 
collaborative innovation and comprehensively enhance the higher level. Improving higher school talents and disciplines, scientific research innovation ability. In terms of the tutor's training plan, the tutor should continuously stimulate students' creative potential and practical application ability according to the specific conditions of the graduate students, combined with professional development and teaching and research, and develop a personalized training goal. In terms of graduate students' own development goals, specific goals that meet individual characteristics should be developed based on individual characteristics, professional knowledge and skills.

\section{3) Constructing the postgraduate training mechanism}

According to the specific requirements of the reform of higher education system, we should pay attention to the cultivation of innovative talents and actively promote the reform of postgraduate training mechanism. Strengthen the training of postgraduate students in basic research and social issues research, and improve students' innovation potential and innovation sensitivity; To establish a cooperation mechanism for universities to undertake major national and regional scientific research tasks, combine national scientific and technological innovation goals and tasks, and insist on improving students' understanding and cognition of international cutting-edge scientific and technological innovation; The cooperation mechanism of joint innovation and training between universities and local enterprises should be established, and the "double mentor" joint training mode of universities, industries and enterprises should be carried out to accelerate the training of compound talents with practical ability and innovation ability. Improve the supervisor responsibility system, give full play to the leading role of the supervisor in postgraduate training, and improve the students' scientific research ability; The system of postgraduate courses should be innovated, the knowledge structure should be optimized and the teaching quality should be improved.

4) Improving the recruitment system for graduate students

A pluralistic recruitment and selection mechanism should be established for graduate students. We should encourage and advocate universities to recruit students on their own initiative, further expand their independent choice of enrollment, and give more independent space to universities, especially "double-tops" universities. We will support part-time professionals to pursue professional master's degrees, encourage people with different disciplinary backgrounds to pursue professional master's degrees in management, and encourage students with different disciplinary backgrounds to communicate and learn from each other. Further promote the development of open education mode and improve the selection mechanism of postgraduates' innovation ability. Pay attention to the assessment of students' comprehensive quality in all aspects, instead of assessing students' ability by a single standard.

\section{5) Optimizing the graduate curriculum system}

The key to the innovation of postgraduate training mode lies in the innovation of postgraduate course system, course content and academic research practice. We can learn from the experience and lessons of foreign postgraduate education practice, start with optimizing the knowledge structure, ability structure and quality structure of graduate students, and reform from the two aspects of curriculum arrangement and teaching mode. On the one hand, the content system of courses should be innovated: the proportion of elective courses should be enriched, the number of compulsory courses should be appropriately reduced, and the interdisciplinary and interdisciplinary course system should be developed. Allow students to take elective courses across majors, colleges and schools; Encourage students to design a curriculum plan that is suitable for their own development. On the other hand, the arrangement of teaching activities should be innovated: the quality of the whole training process should be controlled, and the training planning and quality control of the training process should be implemented into the links of subject research and scientific research practice. The teaching mode emphasizes students' independent thinking and heuristic teaching, and guides students to study and innovate in study. Inspire students' innovative potential and speculative ability through the use of instructor-inspired and student-independent teaching forms.

\section{6) Improving the graduate evaluation system}

It is necessary to change the single academic evaluation method and establish a diversified and differentiated quality evaluation standard system to innovate the evaluation and evaluation content system of graduate student training. Second, in terms of the assessment of the overall academic performance of the discipline, the single assessment and evaluation index based on the academic performance of the students should be changed, and the assessment index of the scientific research ability of the students should be increased, including the comprehensive application of disciplinary knowledge, innovative features of academic papers, innovative perspective on problems, and grasp of practical problems. Third, in the evaluation of the comprehensive quality of postgraduates, learning ability, innovation ability and practical ability as the main evaluation criteria; Fourth, in terms of scientific research and innovation achievements, the degree of contribution to economic construction and social development should be emphasized. The approval rate and contribution rate of graduate projects can be used as evaluation content and scientific research practice assessment.

\section{7) Creating an innovative research atmosphere}

Whether the external environment is creative or not, and whether the students are in a campus with an innovative atmosphere, will directly affect the innovation consciousness, attitude and passion of students, and even affect the improvement of innovation ability. To create a strong atmosphere for campus innovation: first, to establish a supervisor responsibility system led by scientific research, and to implement the supervisor funding system closely related to scientific research; The second is the graduate student innovation project Settings, schools provide special innovation project funding, mentor choose innovative subject, graduate student cooperation declaration, the school organization expert evaluation, to through the review of innovation subject innovation, improve the graduate student grants to improve coverage and intensity, for will grant evaluation combined with graduate student learning, scientific research performance; Third, we will build university science and technology parks, industrial innovation parks and pilot areas for entrepreneurship, 
foster a number of innovative science and technology enterprises, and provide high-tech bases for graduate students to conduct innovative research. Fourth, to build a research center for graduate students, which is a broad platform supported by multiple disciplines, multiple research directions, multiple innovation teams and diversified investment channels Fifth, hold graduate seminars and academic salons to provide a platform for graduate students to think and communicate on research topics; Sixth, to guide graduate students to participate in social enterprise innovation project activities and participate in the research and development of new products and new technologies; Seventh, famous experts, scholars and entrepreneurs in related fields will be invited to universities to give lectures on innovative ideas for postgraduates, so as to promote high-end academic exchanges. Eighth, to create an elegant and positive university culture, to create a free thinking, academic debate, and a study atmosphere in which teachers and students work together. With the rigorous spirit of academic research, free academic atmosphere, harmonious education environment, and firm scientific research will, it is necessary to cultivate graduate students' innovative thinking and improve their innovative practice ability. Gather the innovation energy, form the innovation resultant force, and make the postgraduate training become the highland for the growth of innovative talents in China.

\section{CONCLUSION}

The cultivation of innovative ability and innovative thinking is recognized as the most critical and important part in the process of postgraduate talent cultivation. The scale of higher education in China is getting larger and larger, and there are more and more people with higher education background. At the same time, it is accompanied by the problem of different levels of higher education talents, good and bad. This paper takes the innovation ability as the orientation, faces the local university graduate student teaching reform, carries on the thorough exploration to the management specialized graduate student training mode, proposed to construct the management graduate student innovation ability training mode which takes "the goal orientation" and "the talented person training entire process quality control" as the core.

\section{REFERENCES}

[1] Wei Hongliang, Mao Zesheng, Zhang Xiaorong, Cheng Shiwei. Research on the Cultivation of Masters' Innovative Ability in Economics and Management Majors Based on Constructivism[J]. Modern University Education, 2018(05): 98-105.(In Chinese)

[2] Qin Falan, Hu Chengxiao. Research on goal-oriented postgraduate training mode[J]. Degree and Postgraduate Education, 2014(01): 50-54. (In Chinese)

[3] Chen Zhili. Speech at the 22nd Meeting of the Academic Degrees Committee of the State Council[J]. Degree and Postgraduate Education, 2006, (3): 38. (In Chinese)

[4] Cheng Sihui, Wang Chuanyi. Postgraduate training mode: reality and future [J]. Bachelor of Science And graduate education, 2010, (3): 50-53. (In Chinese)

[5] Zhang Jie, Wang Binsong, Yang Hongyi, Zhang Guocai. The main problems and thinking of postgraduate education and training [J]. Education and Teaching Forum, 2017(44): 198-200. (In Chinese)

[6] Ren Dapeng. Research on the Control Mechanism of Applied Undergraduate Talents Quality[J]. Theoretical Theory, 2018(08): 193195. (In Chinese)

[7] Zhang Xiekui, Zhang Lian. Research on the Cultivation of Innovative Ability of Graduate Students in Regional Economics-Taking Guangxi University as an Example [J]. Higher Education Forum, 2016(01): 4-7. (In Chinese) 